\title{
Opptrappingsplanen for psykisk helse - idealer og realiteter
}

\author{
De siste 10-15 årene har psykiatrien blitt kritisert for ikke å gi et \\ tilstrekkelig godt tilbud til psykiatriske pasienter. Opptrappingsplanen \\ for psykisk helse (1998-2006) skulle rette på dette. Men ble målet om \\ et bedre tilbud nådd? Mye tyder på at det har gått fra dårlig til verre \\ for de aller dårligst stilte psykiatriske pasientene.
}

\section{María Sigurjónsdóttir}

maria.sigurjonsdottir@ulleval.no

Regional sikkerhetsavdeling Helse Sør-Øst

Ullevål universitetssykehus

Sykehusveien 18

1385 Asker

Psykiatrien har lenge vært kritisert for at behandlingstilbudet til psykiatriske pasienter ikke har vært tilstrekkelig. Dette resulterte blant annet i stortingsmeldingen Apenhet og helhet, der det ble rettet sterk kritikk mot flere områder i psykiatrien (1). Rapporten førte til at Stortinget vedtok en opptrappingsplan for psykisk helse (2). Det har gått ti år fra opptrappingsplanen ble vedtatt, men kritikken har likevel ikke stilnet. En av de siste i en lang rekke kritikker er Helsetilsynets rapport om tjenestetilbudet til pasienter med psykiske lidelser fra 2007 (3).

Hvorfor fungerer det psykiatriske tilbudet ikke etter hensikten selv etter gjennomføringen av den ambisiøse opptrappingsplanen? I det følgende sammenliknes de faktiske kapasitetstall i voksenpsykiatrien med de tiltak som ble vedtatt gjennomført i opptrappingsplanen.

\section{Mål og resultater i 2006}

I opptrappingsplanen var det ambisiøse mål, både på kommunalt og fylkeskommunalt nivå (ramme 1). Men er disse målene blitt oppnådd?

Opptrappingsplanen foreskrev en økning $i$ antall senger i psykiatrien, men i stedet har det i perioden skjedd en ganske betydelig reduksjon (tab 1). Det fremgår av tabell 1 at det faktisk $i$ alt var 1575 færre sengeplasser i psykiatrien i 2006 enn det som var forutsatt i opptrappingsplanen ved periodens utløp. Ifølge tall fra Statistisk sentralbyrå har denne utviklingen fortsatt, slik at det i 2007 er 1796 færre senger enn forutsatt i opptrappingsplanen (4).

Tallene ovenfor sier ingenting om kvaliteten på behandlingen i døgnomsorgen, men den forutsatte økningen i sengeplasser ved psykiatriske sykehus er paradoksalt blitt til en markant reduksjon. Fra 1996 til 2006 er det riktignok blitt en betydelig økning i antall døgnplasser ved distriktspsykiatriske sentre (DPS), men antall senger totalt ligger fortsatt klart under det som ble planlagt. I tillegg har det vært stor nedskjæring i senger ved psykiatriske sykehjem, slik at det kun er få senger igjen. Dette var ikke forutsatt i opptrappingsplanen.

Kongstanken i opptrappingsplanen var å øke antall polikliniske konsultasjoner i psykisk helsevern med $50 \%$. Ut fra dette skulle måltallene for 2006 være 660000 konsultasjoner. Ifølge Statistisk sentralbyrå var i 2006 antall polikliniske konsultasjoner 956000 (4). Tallene fra 1996 og 2006 bygger ikke helt på samme datagrunnlag. Telefoniske konsultasjoner inngår i tallene for 2006, men var ikke med i 1996. I tillegg har det de siste ti årene vært jobbet intenst med å forbedre registrering i aktivitet ved de distriktspsykiatriske sentrene. Likevel er økningen fra 440000 konsultasjoner til 956000 mer enn en dobling av antall konsultasjoner, og det er lite sannsynlig at forbedringer i registrering eller antall telefoniske konsultasjoner kan forklare en så stor økning. Målet om 50\% økning av polikliniske konsultasjoner er uten tvil nådd, og den reelle veksten er trolig omkring $100 \%$ i perioden 1996-2006.

For de resterende mål for fylkeskommunale tiltak eller helseforetakenes tiltak har det vært vanskelig å fremskaffe tilstrekkelig konklusive data. Antall årsverk av psykiatere og psykologer er økt. Allikevel påpeker Legeforeningens rapport fra 2008 om lokalsykehusfunksjoner i psykisk helsevern at det fremdeles mangler om lag 500 psykiatere og om lag 600 psykologer i landets distriktspsykiatriske sentre (5).

Opptrappingsplanen hadde som mål å etablere 3400 nye omsorgsboliger i kommunene frem til 2006. Dette skulle skje i tillegg til økning av senger innenfor fylkeskommunale tjenester eller helseforetak. Per 11. november 2008 var det blitt opp- rettet 3019 omsorgsboliger gjennom opptrappingsmidler (6). I 2007 hadde man oppnådd $83 \%$ av det planlagte økte antall årsverk i den kommunale voksenpsykiatrien (6). Det er da oppsiktsvekkende at Helsetilsynets rapport fra 2007 allikevel diskuterer betydelige boligproblemer for psykiatriske pasienter (3). Her anslås behov for 200-300 nye boliger i hver av de større byene uten at det presiseres hvilke byer det er snakk om. Ifølge rapporten oppholder disse pasientene seg i psykiatriske institusjoner, hos pårørende eller i rehabiliteringstilbud over lengre tid. Det fremgår også at det mangler helsearbeidere og tverrfaglig kompetanse for å gi tjenester til psykisk syke i flere kommuner (3).

\section{Ramme 1}

\section{Opptrappingsplanens mål for voksenpsykiatrien}

Fylkeskommunale tiltak for voksne:

- Kvantitativ og kvalitativ styrking og omstrukturering av døgntilbudet i voksenpsykiatrien

- 1185 nye døgnplasser for aktiv behandling (160 nye sykehusplasser til personer som dømmes til psykiatrisk behandling, resten i DPS)

- 220000 flere polikliniske behandlinger/konsultasjoner (+50\%)

- $50 \%$ flere privatpraktiserende psykiatere og psykologer med driftsavtale

- 90000 flere dagopphold ved de distriktspsykiatriske sentrene (+50\%)

- Styrking av tilbudet for grupper med særlige behov (bl.a. rusmisbrukere med psykiske lidelser, flyktninger og asylsøkere, psykisk utviklingshemmede og døvel og den samiske befolkningen med psykiske lidelser

Kommunale tiltak for voksne:

- 3400 nye omsorgsboliger for mennesker med psykiske lidelser

- 3400 flere årsverk i hjemmetjenesten

- 4500 flere brukere av dagsentre

- 10000 flere skal få tilbud om støttekontakt

- 15000 flere skal få tilbud om kulturog fritidstiltak

- Styrking av behandlingstilbudet (184 psykologer og 125 flere høyskoleutdannet personell med tilleggsutdanning i psykiatril 


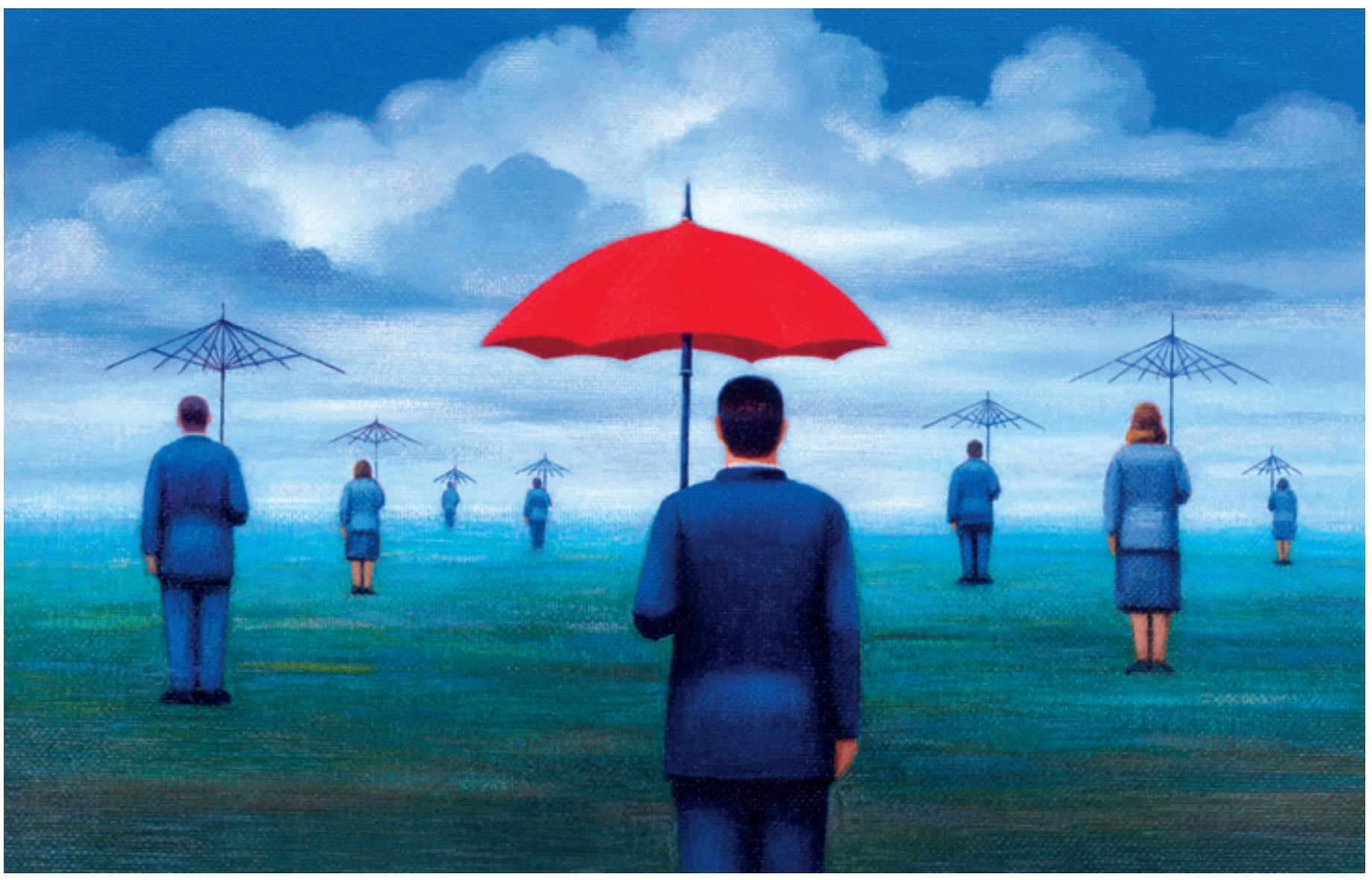

Illustrasjon Corbis/SCANPIX

\section{En katastrofe for de dårligste}

Det har inntruffet betydelige endringer i psykiatrien i perioden 1996-2006. Enkelte vil hevde at til tross for nedskjæringer i sengeplasser må resultatene av opptrappingsplanen få karakteren godkjent, ettersom veksten i polikliniske konsultasjoner er så stor at den oppveier nedskjæringen i sengeplasser.

Det er liten tvil om at pasienter som kan nyttiggjøre seg poliklinisk behandling har fått et betydelig bedret tilbud. Dette gjelder i alle fall på de distriktspsykiatriske sentrene der det finnes tilstrekkelig spesialistkompetanse til å gi slik behandling, men mangel på spesialister i psykiatri og psykologi er fortsatt et betydelig problem.

Ikke alle psykiatriske pasienter drar nytte av økningen i polikliniske tilbud. Pasienter som sliter med tilbaketrekning og mangel på initiativ som følge av sin lidelse, vil i dårlige perioder ha problemer med å møte til avtaler. Andre mangler sykdomsinnsikt og unndrar seg behandling. Pasientene kan også være farlige overfor seg selv og/eller andre, noe som gjør poliklinisk behandling meget vanskelig. Det finnes psykiatriske pasienter som ikke klarer å ta vare på seg selv, enten det dreier seg om kortere eller lengre perioder. Andre pasienter har betydelige psykiatriske symptomer og atferdsavvik som vanskeliggjør behandling utenfor insti- tusjon. Noen pasienter i disse gruppene har fastlåste tilstander. Til tross for meget langvarig behandling i døgninstitusjoner blir ikke alle pasientene så bra at de kan leve selvstendige liv utenfor institusjon.

Det finnes derfor fortsatt et betydelig antall pasienter som trenger innleggelse over lengre tid for å få tilstrekkelig og forsvarlig psykiatrisk behandling. En stor del av pasientene med alvorlig voldsproblematikk trenger tilsyn og oppfølging på psykiatriske sykehus med høy bemanning i lengre tid, før det i det hele tatt vurderes å sende dem videre til lavere behandlingsnivå, som oftest til lettere bemannede sengeposter ved de psykiatriske sykehusene. Pasienter som over tid utgjør fare for andre, eller som sliter med å ta vare på seg selv, trenger ofte omfattende tverrfaglige tjenester for å sikre samfunnsvern og for å bedre sin funksjon.

Ettersom det blir færre psykiatriske senger, blir en forholdsmessig større andel av sengene belagt av pasienter fra disse gruppene. Selv om pasientene skulle bli noe bedre, lar de seg ikke nødvendigvis videreføre til andre behandlingstilbud. Mindre bemannede enheter i psykiatrien har ofte problemer med å gi disse pasientgruppene tilstrekkelige behandlingstilbud. Og kommunene vegrer seg for å ta imot dem, da de mener at de ikke har tilstrekkelige tilbud eller tilstrekkelig fagkompetanse. I Helsetilsynets rapport kommer det frem at det kan dreie seg om 10-50 pasienter i fylket eller helseforetaket (3).

Disse pasientene synes ikke å passe godt inn i den tenkte modellen av psykiatrien, da de ikke «flyter» videre i behandlingskjeden i retning poliklinikk og så videre til første linje tjenesten i kommunene. Det er dessuten tankevekkende at psykiatrien ønsker «flyt» av pasienter, til tross for at forutsetningen for slikt «flyt» pleier å være brudd på relasjoner til behandler og/eller miljø som pasientene er trygge på.

Det har ikke kommet nye behandlingsmetoder for ovenfornevnte pasientgrupper i perioden 1996-2006 som skulle tilsi at det er redusert behov for psykiatriske senger. Kommunene har heller ikke maktet å bygge opp sine tjenester slik at de kan gi disse pasientene døgnbaserte tjenester hjemme eller i omsorgsboligene, som dessverre heller ikke finnes i tilstrekkelig grad (7). Konklusjonen må bli at kommunene ikke har ressurser til å gi tyngre psykiatriske pasienter de tjenester de trenger for å kunne bo utenfor institusjon. Polikliniske konsultasjoner eller lavt bemannede DPS-sengeposter er heller ikke et tilstrekkelig tilbud til disse gruppene.

\section{Konklusjon}

Det synes derfor som om forskyvning av kapasitet i retning poliklinisk behandling har gått på bekostning av meget syke psykiatriske pasienter som trenger innleggelser 
Tabell 1 Resultatmål for psykiatriske senger i perioden 1996-2006

\begin{tabular}{lcccc} 
& $\begin{array}{c}\text { Antall } \\
\text { senger } \\
1996\end{array}$ & $\begin{array}{c}\text { Opptrappings- } \\
\text { planens mål } \\
\text { for senger } \\
\text { i } 2006\end{array}$ & $\begin{array}{c}\text { SINTEF-SAMDATA } \\
\text { og Statistisk sen- } \\
\text { tralbyrå 2006 }\end{array}$ & $\begin{array}{c}\text { Forskjeller } \\
\text { mellom antall } \\
\text { planlagte og faktisk } \\
\text { opprettede senger }\end{array}$ \\
Type sengeplass & 2940 & 3100 & 2831 & -269 \\
\hline Sykehusavdelinger & 1040 & 2065 & 1956 & -109 \\
\hline DPS-døgn & 2300 & 1400 & 141 & -1259 \\
\hline $\begin{array}{l}\text { Psykiatriske sykehjem } \\
\text { Andre typer sengeplasser }\end{array}$ & 0 & 0 & 62 & +62 \\
likke-definerte) & 6280 & 6565 & 4990 & -1575 \\
\hline $\begin{array}{l}\text { Psykiatriske sengeplasser } \\
\text { i Norge }\end{array}$ & & & &
\end{tabular}

i psykiatrien. Denne utviklingen har gått mye lenger enn forutsatt, slik at man i 2006 har $24 \%$ færre senger i psykiatrien enn det som var planlagt mot slutten av opptrappingsplanen. Underkapasitet på døgnplasser i psykiatriske sykehus synes å være en av grunnene til at psykiatrien fortsatt kritiseres for å gi manglende behandlingstilbud til psykiatriske pasienter. Dessverre er det de alvorlig syke pasientene og deres pårørende som lider mest som følge av manglene på døgntilbud i psykiatrien.

Oppgitte interessekonflikter: Ingen

\section{Litteratur}

1. St.meld. nr. 25 (1996-97). Åpenhet og helhet. Om psykiske lidelser og tjenestetilbudene. www.regje- ringen no/nb/dep/hod/dok/regpubl/stmeld/ 19971998/st.meld-nr-25_1996-97.html?id=191086 (6.2.2009).

2. St.prp. nr. 63 (1997-98). Om opptrappingsplan for psykisk helse 1999-2006. www regieringen no/nb/ dep/hod/dok/regpubl/stprp/19971998/Stprp-nr63-1997-98.html?id=201915 (6.2.2009)

3. Statens helsetilsyn. Rapport nr. 8/2007. Tjenestetilbudet til personer med psykiske lidelser. www.helsetilsynet.no/upload/publikasjoner/ rapporter2007/helsetilsynetrapport8_2007.pdf (6.2.2009).

4. Statistisk sentralbyrå. Fleire spesialistar i psykisk helsevern. www.ssb.no/speshelsepsyk/main.html (6.2.2009).

5. Den norske legeforening. Lokalsykehusfunksjoner i psykisk helsevern. Lokalsykehusenes fremtidige rolle. Oslo: Den norske legeforening, 2008: 3-4.

6. SINTEF SAMDATA Sektorrapport Psykisk helsevern 2006. Trondheim: SINTEF, 2006. www.sintef. no/Projectweb/Startsiden/SAMDATA-pa-nett/ SAMDATA-2006/Sektorrapport-Psykisk-helsevern-2006/ (6.2.2009)

7. SINTEF. SAMDATA. Psykisk helsearbeid

i kommunene: Disponering av statlig øremerkede midler 1999-2007. www.sintef.no/upload/Helse/ Psykisk \%20helse/Pdf-filer/Disponering øremerkede midler 1999-2007.pdf

Manuskriptet ble mottatt 2.7. 2008 og godkjent 25.2. 2009. Medisinsk redaktør Anne Kveim Lie. 